There was no increase in the total carrier-rate during the stay of patients in the cubicle ward, and only a small rise in the percentage carrying staphylococci resistant to two or more antibiotics.

The rate of appearance of new strains of Staph. aureus on successive swabbing was investigated as a possible measure of the exposure of patients to infection. Isolation in cubicles did not have much effect on the rate of apparent acquisition of staphylococci sensitive to antibiotics or resistant only to penicillin, but it reduced considerably the rate for organisms resistant to two or more antibiotics.

It seemed likely that many of the "acquisitions" were artifacts, due to the intermittent isolation of organisms carried before admission. For this reason, the rate of apparent acquisition of multiple-resistant strains-which are less often found in the nose of patients on admission-is a more sensitive index of exposure to infection in hospital than the rate of apparent acquisition of all strains of Staph. aureus.

No likely source could be found for two-thirds of the apparent acquisitions. About half of the remainder could be attributed to infection from the staff and half to infection from patients in other cubicles. The rate of acquisition of strains from known sources might be a valuable measure of the effect of ward design on the risk of acquiring a hospital staphylococcus.

We are indebted to Dr. O. M. Lidwell and Dr. M. Patricia Jevons for helpful advice, and to Mr. G. McGimpsey and Mr. Ian Rae for technical assistance.

\section{REFERENCES}

Barber, M. (1947). f. Bath. Bact., 59, 373.

Csillag, A., and Medway, A. J. (1958). Brit. med. F., 2, 1377. Dutton, A. A. C., Beard, M. A., Elmes, P. C., and Williams, R (1960). Ibid., 1, 11 .

Parker, M. T., and Jevons, M. P. (1963). In Infection in Hospitals, edited by R. E. O. Williams and R. A. Shooter, p. 55. Blackwell, Oxford.

Report (1965). To be published.

Shooter, R. A., Thom, B. T., Dunkerley, D. R., Taylor, G. W., Parker, M. T., John, M., and Richards, I. D. G. (1963). Brit. med. \}., 2, 1567.

Stuart, R. D., Toshach, S. R., and Patsula, T. M. (1954). Canad. F. publ. Hlth, 45, 73.

Williams, R. E. O.'(1959). Lancet, 1, 190. Jevons, M. P., Shooter, R. A., Hunter, C. J. W Griffiths, J. D., and Taylor, G. W. (1959). Brit. med. F., 2, 658 . Noble, W. C., Jevons, M. P., Lidwell, O. M., Shooter, R A., White, R. G., Thom, B. T., and Taylor, G. W. (1962). Ibid., 2, 275

and Rippon. J. E. (1952). F. Hyg. (Lond.), 50, 320.

\title{
Crushed Chest Injury: Some Physiological Disturbances and Their Correction
}

\author{
J. M. REID,* M.B., CH.B., F.F.A. R.C.S., D.A., ; W. L. M. BAIRD, $†$ M.B., CH.B., F.F.A. R.C.S., D.A.
}

Brit.'med. F., 1965, 1, 1105-1109

Although still a relatively uncommon injury, there is an increasing incidence of severe thoracic and pulmonary damage, due principally to high-speed motoring accidents. This type of injury, which was formerly associated with mining accidents, is commonly referred to as the crushed chest injury or stove-inchest. There may be multiple posterior or anterior fractures of ribs and fractures of the sternum or a mixture of such fractures.

Griffiths (1960), reviewing the literature, has summarized the advantages of treatment by intermittent positive-pressure ventilation (I.P.P.V.) over mechanical fixation. Nevertheless, the results remain somewhat disappointing.

In a series of 33 cases treated in the Respiratory Emergency Unit of Glasgow Royal Infirmary during the past two years it has become evident that an explanation for many disappointing results can be traced to our previous inability to measure the severity of the respiratory and metabolic disturbances that result from this form of trauma. The recent development of simple biochemical techniques and their application at the bedside now make it possible to assess rapidly the severity of the initial disturbances, to aid the selection of the correct treatment, and to follow at frequent intervals the effectiveness of the treatment.

\section{Respiratory and Metabolic Disturbances}

The term "crushed chest injury" implies considerable violence to the thorax, and this must result in damage to the

\footnotetext{
* Consultant, University Department of Anaesthetics, Glasgow Royal Infirmary.

† Consultant, University Department of Anaesthetics, Glasgow Royal Infirmary.
}

lungs, as suggested by Harley (1961) (Fig. 1). The disruption of alveolar structure, interstitial and intra-alveolar haemorrhage, and atelectasis due to plugging of the bronchioles with secretions and debris are evident. Alteration in the alveolar ventilation/blood perfusion ratio $(V / P$ ratio) is inevitable in the affected segments of the lungs. This leads to a reduction

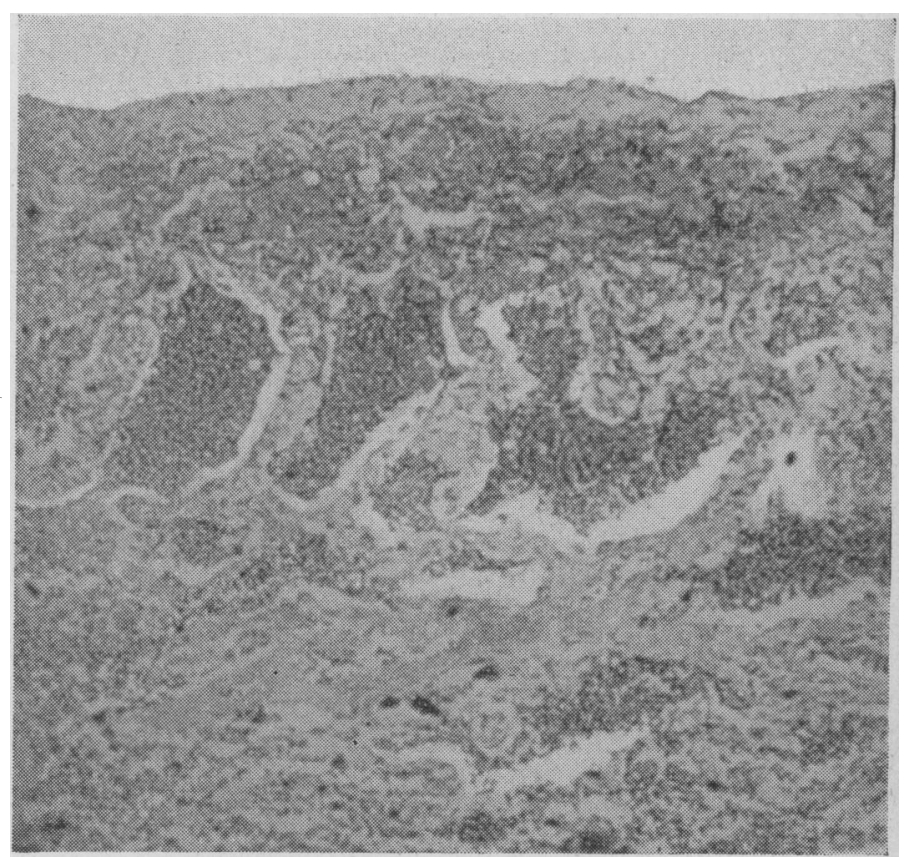

FIG. 1.-Demonstrating damage to the lungs. 
in the oxygen content of the arterial blood, although carbon dioxide elimination may be virtually unimpaired (Comroe et al., 1962). Continuing haemorrhage, lobular atelectasis due to secretions, haemothorax and/or pneumothorax, pain, and central depression of respiration due to injury or analgesic drugs will cause the oxygen content of the arterial blood to fall further. Finally, when lung failure is imminent the carbon dioxide content of the arterial blood will rise and acidosis will supervene.

The overall reflex response to this state of hypoxia and hypercarbia is an attempt to improve alveolar ventilation principally by increasing the rate of respiration. Thus the work of ventilation is increased, and therefore oxygen consumption will rise. The efficiency of this response' is further impaired by the trauma to ribs and muscles of respiration, although Maloney et al. (1961) question the validity of intrapulmonary shunting of air due to a flail segment.

Severe loss of blood is a major problem in such patients, who have often sustained other multiple injuries. Vasoconstriction occurs, and the consequent reduction in arterial perfusion of the tissues results in a metabolic acidosis. If the haemorrhage is of sufficient magnitude the cardiac output falls, increasing the severity of the metabolic acidosis.

Freeman (1963) has stressed the occurrence of metabolic acidosis as the consequence of stagnant hypoxia after severe haemorrhàge. He has drawn attention to the great increase in the amount of dead-space ventilation that results. To maintain a normal oxygen content of arterial blood a considerable increase in total ventilation would therefore be required.

The acidity, the high potassium-ion content, and the citrate content of stored blood, which may be required in large volumes during the initial resuscitation, increase the problems (Bull, 1963).

Concomitant head injuries and unconsciousness are common. The effects of an obstructed airway in these cases are too well known to require further comment.

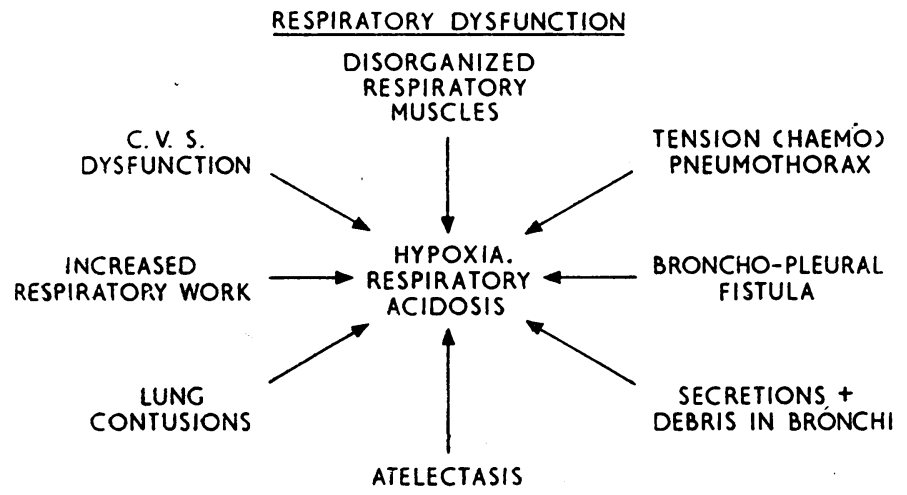

Fig. 2-Summarizing the disturbances of the respiratory system.

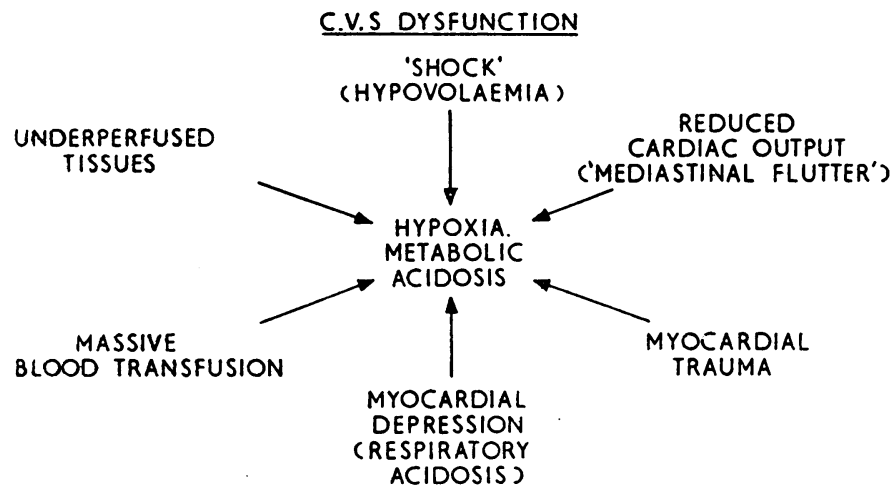

Fig. 3.-Summarizing the disturbances of the cardiovascular system.
A degree of renal failure presumably related to the hypotension, acidosis, and hypoxia is often present, and, indeed, acute tubular necrosis may occur.

In reviewing the literature we have noted the emphasis on the extent of the bony injuries, particularly in the earlier reports. Little attention has been paid to the direct damage to the lungs and to the interrelationship of the disturbances of the respiratory and cardiovascular systems (Figs. 2 and 3).

\section{Outline of Management}

As rapidly as possible plasma and stored blood are used to correct the hypovolaemia. The consequent increase in metabolic acidosis justifies the empirical administration of sodium bicarbonate solution intravenously-for example, $100 \mathrm{mEq}$ in an adult. A sample of arterial blood is obtained as soon as is feasible, and the following measurements are made: (1) $\mathrm{pH}$, arterial carbon dioxide tension $\left(\mathrm{PaCO}_{2}\right)$, standard bicarbonate, base excess, and buffer base (Astrup, 1959 ; Andersen et al., $1960)$; (2) oxygen saturation $\left(\mathrm{SaO}_{2}\right)$-by means of the Kipp haemoreflector ; and (3) where possible the tension of oxygen in arterial blood $\left(\mathrm{PaO}_{2}\right)$. Collectively these measurements are referred to as blood-gas analysis.

Ás a result of biochemical and clinical assessment (including radiological examination) we have found it possible to place the cases in one of three arbitrary classes. This not only assists discussion but is also of some clinical value.

\section{Class 1}

The extent of the thoracic injury varies, and pneumothorax and/or haemothorax may be present. These patients have a reduced oxygen and carbon dioxide content in the arterial blood (Whitwam and Norman, 1964). Clinically this group is distinguished by the patient's ability to cough effectively so that the airway remains clear of secretions. Spontaneous respiration is always maintained.

The treatment of these patients is conservative, consisting of (a) broad-spectrum antibiotic, (b) frequent physiotherapy, and (c) continuous axygen, which is administered as soon as possible after injury. We prefer the nasal catheter (or modifications) with low flow of oxygen because expectoration and eating are possible while breathing oxygen-enriched air.

We administer analgesics-for example, morphine (at first intravenously), and do not employ analgesic/antagonist mixtures, as their efficiency has been questioned (Telford and Keats, 1961).

Frequent blood-gas analyses are essential so that the patient's condition can be accurately and continually assessed. Early improvement is usually seen (Table I), as in the patient (Case 28) who had fractures of nine successive ribs and a haemopneumothorax which required drainage. However, it may be a few days before the arterial blood is fully oxygenated.

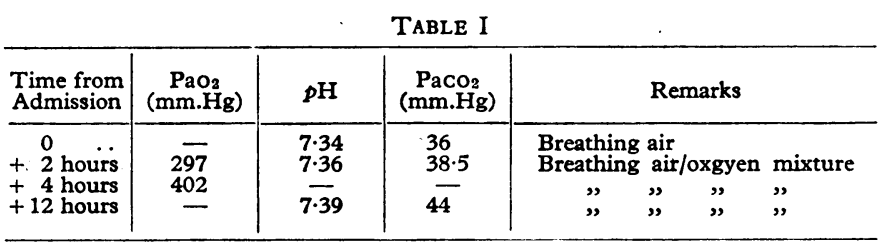

\section{Class 2}

These patients have usually sustained inore serious injuries, including non-thoracic injuries. The level of consciousness may be impaired. The oxygen content of the arterial blood is reduced and the carbon dioxide content is also lowered, 
although the latter is more difficult to assess in patients with pre-existing obstructive lung disease.

However, in contrast to those in Class 1, these patients are unable to cough effectively, and therefore require tracheostomy and aspiration of bronchial secretions to maintain a clear airway.

The general management is as outlined above, but because of the tracheostomy the oxygen or oxygen/air mixture must be humidified. The oxygen content of the arterial blood rises to normal, although this may occur during a few days rather than immediately. The carbon dioxide content of the arterial blood remains satisfactory because of the maintenance of a clear airway and reduction in dead space.

Some patients, however, deteriorate into Class 3.

\section{Class 3}

These patients have acute progressive (uncompensated) respiratory failure. The oxygen content of arterial blood is low, the $p \mathrm{H}$ is low, and the partial pressure of carbon dioxide is high. Metabolic acidosis is often present. Typically, multiple injuries are present, and these are both extensive and severe. Almost always there is a haemopneumothorax, occasionally bilateral. Hypovolaemic shock is present.

Intermittent positive-pressure ventilation is begun through a cuffed endotracheal tube employing $100 \%$ oxygen. The blood volume is restored as soon as possible. The patient's condition usually improves rapidly, so that tracheostomy, insertion of water-seal drain, laparotomy, etc., can be performed without undue haste.

Thereafter the patient is ventilated by a mechanical ventilator employing $100 \%$ oxygen, sedation, analgesia, and a muscle relaxant. It is rare for the oxygen content of the arterial blood to rise to normal for some days. The ventilator is adjusted to maintain the carbon dioxide level in arterial blood within normal limits as determined by frequent blood-gas analyses.

However, two types of patients require further discussion. (a) In the patient with severe pre-existing obstructive lung disease hyperventilation will not always correct the respiratory acidosis (Table II). In such cases the combination of ventilation and trihydroxymethylaminomethane is warranted (Nahas, 1963) (Table II). This patient (Case 29) subsequently made a good recovery, although splenectomy, and, later, laparotomy for division of adhesions, were required. (b) Occasionally the oxygen content of the arterial blood is very low, whereas the carbon dioxide content is only moderately raised (Case 5). This case has already been reported in detail (Kennedy et al., 1963). A relatively satisfactory oxygen content of the arterial blood was not achieved until mechanical ventilation with pure oxygen was begun.

\begin{tabular}{|c|c|c|c|c|c|}
\hline Time & $\begin{array}{l}\mathrm{SaO}_{2} \\
(\%)\end{array}$ & $p \mathrm{H}$ & $\begin{array}{c}\mathrm{Paco}_{2} \\
\underset{\mathrm{Hg}}{(\mathrm{mm})}\end{array}$ & $\begin{array}{l}\text { *St. Bic. } \\
\text { (mEq/. } \\
1 . .)\end{array}$ & Ventilation \\
\hline Admission & 70 & $7 \cdot 27$ & 80 & 25 & Spontaneous, breathing oxygen/ \\
\hline+30 min. . & & $7 \cdot 26$ & 82 & 25 & $\begin{array}{l}\text { art } \\
\text { Hyperventilation by anaesthetist } \\
\text { with } \mathrm{CO}_{2} \text { absorption and } \\
100 \% \mathrm{O}_{2}\end{array}$ \\
\hline \multicolumn{6}{|c|}{$\begin{array}{l}\text { Trihydroxymethylaminomethane } 18 \mathrm{~g} \text {. infused } \\
+2 \mathrm{hr} .45 \mathrm{~min} .\end{array}$} \\
\hline $\begin{array}{l}+2 \mathrm{nr} .45 \mathrm{~min} \\
+4 \mathrm{hr} .15 \mathrm{~min}\end{array}$ & & & 50 & 37 & $\begin{array}{l}\text { Mechanical ventilation }+100 \% \\
\mathrm{O}_{2}\end{array}$ \\
\hline
\end{tabular}

*St. Bic. $=$ Standard bicarbonate.

Within a few days the dosage of sedative, analgesic, and muscle relaxant can be reduced and finally discontinued. After the oxygen content of the arterial blood has been normal for some days the concentration of oxygen in the inspired gas can be slowly reduced. Reduction in the oxygen content of the arterial blood again occurs if this is undertaken too rapidly. Finally the patient is ventilated with humidified air.
When "weaning" from the ventilator is started-that is, allowing the patient to breathe spontaneously for one to two minutes-a fall in oxygen content of the arterial blood occurs if the patient is breathing air. The patient must therefore breathe an oxygen-enriched atmosphere during "weaning," and this is allowed to continue only provided that the oxygen and carbon dioxide content of the arterial blood remains substantially normal.

\section{Discussion of Results}

During two years 33 cases of crushed chest injury were treated, and $21(63 \%)$ survived (Table III, overleaf). All patients in Class 1-that is, those who required only conservative management-survived (Table IV). The survival rate of patients who could not cough effectively, and therefore required tracheostomy in addition to conservative management, was $62.5 \%$. In this series the deaths in Class 2 occurred in elderly patients (69 to 80 years). The combined survival rate for 17 patients who did not require ventilatory therapy was $82.4 \%$ (Classes 1 and 2).

TABLE IV.-Summarizing Patients in Their Respective Classes

\begin{tabular}{|c|c|c|c|c|c|c|}
\hline \multirow{2}{*}{ Class } & \multirow{2}{*}{ No. } & \multicolumn{2}{|c|}{ Surviving } & \multirow{2}{*}{$\begin{array}{c}\text { No. With } \\
\text { Obstructive } \\
\text { Lung } \\
\text { Disease } \\
\text { Prior to } \\
\text { Injury }\end{array}$} & \multirow{2}{*}{$\begin{array}{l}\text { No. With } \\
\text { Serious } \\
\text { Non- } \\
\text { Thoracic } \\
\text { Injury }\end{array}$} & \multirow{2}{*}{ Remarks } \\
\hline & & No. & $\%$ & & & \\
\hline 1 & 9 & 91 & 100 & 4 & 3 & $\begin{array}{l}\text { Only one patient with ob- } \\
\text { structive lung disease had } \\
\text { other serious injury. }\end{array}$ \\
\hline 2 & 8 & 5 & $62 \cdot 5$ & 4 & 3 & $\begin{array}{l}\text { The } 3 \text { patients who died were } \\
\text { aged over } 69 \text { and had ob- } \\
\text { structive lung disease }\end{array}$ \\
\hline 3 & 16 & 7 & 43.75 & 8 & 12 & $\begin{array}{l}\text { Two patients who had } \\
\text { hepatorenal failure died sud. } \\
\text { denly. Only one patient was } \\
\text { aged over } 70 \text {, and he died. }\end{array}$ \\
\hline Total & 33 & 21 & 63 & 16 & 18 & \\
\hline
\end{tabular}

The survival rate in 16 patients who required mechanical ventilation was $44 \% ; 12$ cases $(75 \%)$ had serious non-thoracic injuries. Of the 24 patients who required tracheostomy or tracheostomy plus ventilation $50 \%$ survived (Classes 2 and 3 ).

The incidence of pre-existing obstructive lung disease was almost $50 \%$ in each class. Its influence on prognosis in this series is difficult to assess. The three patients in Class 2 who died had pre-existing obstructive lung disease but were elderly ; on the other hand, three of the seven survivors in Class 3 had clinical evidence of this disease.

Acute tubular necrosis requiring dialysis occurred in three patients. It was always possible to dialyse these patients, although they required simultaneous mechanical ventilation. Two patients had combined hepato-renal failure, and they died suddenly. One of these patients had been dialysed on one occasion.

With one exception all patients with a tracheostomy developed a serious pulmonary infection. The commonest organism was penicillin-resistant Staphylococcus aureus. Despite aseptic precautions during aspiration of bronchial secretions the incidence of pulmonary infection has remained high. Barrier nursing of infected patients in individual cubicles cannot be undertaken at present in this unit.

We have routinely administered sodium bicarbonate solution to correct metabolic acidosis rather than the amine buffer trihydroxymethylaminomethane, although this practice is open to several theoretical objections. The principal objection is that sodium bicarbonate is a weak titrating agent producing excess carbon dioxide, whereas trihydroxymethylaminomethane is an intracellular as well as an extracellular buffer, although respiratory depression can follow its administration (Nahas, 1963). 
As has been implied before, frequent blood-gas analysis is necessary to detect any deterioration in the patient's respiratory state. We have employed oxygen saturation as a measurement of change of oxygen content of arterial blood, although direct measurement of the oxygen tension in arterial blood is more sensitive because of the shape of the oxygen-dissociation curve of blood.

Indeed to focus attention on the prime importance of the trauma to the lung and to concentrate treatment on the respira- tory disability we suggest that a better term than crushed chest injury is acute traumatic lung failure.

\section{Summary}

The pulmonary pathology following crushed chest injuries is discussed with emphasis on the consequent derangements of the respiratory and cardiovascular systems. A classification is

Table III.-Clinical Details of Patients

\begin{tabular}{|c|c|c|c|c|c|c|c|c|c|c|c|}
\hline $\begin{array}{l}\text { Case } \\
\text { No. }\end{array}$ & Age & $\begin{array}{l}\text { Pulmonary } \\
\text { Trauma } \\
\text { on } X \text {-ray }\end{array}$ & $\begin{array}{c}\text { Obstructive } \\
\text { Lung } \\
\text { Disease }\end{array}$ & Head Injury & Bony Thoracic Injury & Other Injuries & $\begin{array}{l}\text { Renal or Hepatic } \\
\text { Failure }\end{array}$ & Tracheostomy & I.P.P.V. & Class & Result \\
\hline 1 & 46 & Yes & Yes & Concussion & None & $\begin{array}{l}\text { Facio-maxillary and } \\
\text { forearm fractures. } \\
\text { Haematuria }\end{array}$ & Oliguria only & *E.T.T. & $10 \mathrm{hrs}$. & 3 & Survived \\
\hline 2 & 20 & Yes & None & Concussion & None & $\begin{array}{l}\text { Rupture of spleen. } \\
\text { Laceration of liver. } \\
\text { Retroperitoneal } \\
\text { haematoma. } \\
\text { Fractured femur }\end{array}$ & $\begin{array}{l}\text { Renal and hepatic } \\
\text { failure }\end{array}$ & Yes & 6 days & 3 & Died \\
\hline 3 & 57 & None & Yes & None & 7 ribs & $\begin{array}{l}\text { Retroperitoneal } \\
\text { haemorrhage. } \\
\text { Fractured pelvis } \\
\text { and humerus }\end{array}$ & $\begin{array}{l}\text { One renal dialysis } \\
\text { required. Hepatic } \\
\text { failure }\end{array}$ & Yes & 13 days & 3 & Died \\
\hline 4 & 55 & Yes & Yes & None & $\begin{array}{l}\text { Multiple fractures of } \\
\text { ribs and sternum }\end{array}$ & Fractured patella & Transient jaundice & Yes & 19 days & 3 & Survived \\
\hline 5 & 20 & Yes & None & Unconscious & $\begin{array}{l}\text { ribs and sternum } \\
\text { None }\end{array}$ & $\begin{array}{l}\text { Peritoneal haemorr- } \\
\text { hage. Laceration of } \\
\text { liver }\end{array}$ & $\begin{array}{l}\text { Required renal dia- } \\
\text { lysis on } 10 \text { occasions }\end{array}$ & Yes & 33 days & 3 & Survived \\
\hline 6 & 80 & Yes & Yes & None & $\begin{array}{l}6 \text { ribs (L.), } 2 \text { ribs (R.) } \\
\text { fractured }\end{array}$ & $\begin{array}{l}\text { Ruptured diaphragm. } \\
\text { Compound fracture } \\
\text { of lower leg }\end{array}$ & Transient oliguria & Yes & Nil & 2 & Died \\
\hline 7 & 59 & None & None & None & $\begin{array}{l}3 \text { fractured ribs. } \\
\text { Pneumothorax }\end{array}$ & Fractured lower leg & Transient oliguria & Yes & Nil & 2 & Survived \\
\hline 8 & 69 & Yes & Yes & None & 6 fractured ribs. & None & None & Yes & Nil & 2 & Died \\
\hline 9 & 46 & Yes & Yes & None & Fracture of 3 ribs and & None & None & No & Nil & 1 & Survived \\
\hline 10 & 62 & Yes & Yes & $\begin{array}{l}\text { Fracture or } \\
\text { skull and } \\
\text { brain damage }\end{array}$ & $\begin{array}{l}\text { scapula } \\
\text { Fractured ribs. } \\
\text { Pneumothorax }\end{array}$ & Pott's fracture & Oliguria only & Yes & 7 days & 3 & Died \\
\hline 11 & 25 & Yes & None & $\begin{array}{l}\text { Drain damage } \\
\text { None }\end{array}$ & $\begin{array}{l}\text { Paralysis of hemidia- } \\
\text { phragm and exten- } \\
\text { sive contusion of }\end{array}$ & Fractured left femur & None & Yes & 1 day & 3 & Died \\
\hline 12 & 48 & Yes & None & $\begin{array}{c}\text { Intracranial } \\
\text { injuries }\end{array}$ & $\begin{array}{l}\text { lung } \\
\text { rubs }\end{array}$ & $\begin{array}{l}\text { Fractures of pelvis } \\
\text { and forearm. } \\
\text { Haematuria }\end{array}$ & Oliguria only & Yes & 2 days & 3 & Died \\
\hline 13 & 62 & Yes & Yes & $\begin{array}{l}\text { Intracranial } \\
\text { damage sus- } \\
\text { pected }\end{array}$ & Multiple fractures & None & $\begin{array}{l}\text { Required renal dia- } \\
\text { lysis twice }\end{array}$ & Yes & 15 days & 3 & Died \\
\hline 14 & 42 & Yes & Yes & $\begin{array}{l}\text { pected } \\
\text { Fracture of } \\
\text { mandible. } \\
\text { Intracranial } \\
\text { injury }\end{array}$ & $\begin{array}{l}\text { Multiple fractures of } \\
\text { ribs }\end{array}$ & None & Oliguria only & Yes & 6 days & 3 & $\begin{array}{l}\text { Survived resi- } \\
\text { dual cerebral } \\
\text { damage }\end{array}$ \\
\hline 15 & 45 & Yes & None & None & $\begin{array}{l}\text { Multiple fractures of } \\
\text { ribs }\end{array}$ & $\begin{array}{l}\text { Bilateral fracture of } \\
\text { patellae }\end{array}$ & None & Yes & & 2 & Survived \\
\hline 16 & 47 & Yes & None & None & $\begin{array}{l}\text { Multiple fractures of } \\
\text { ribs. Tension } \\
\text { pneumothorax }\end{array}$ & None & & Yes & 5 days & 3 & Survived \\
\hline 17 & 53 & Yes & Yes & None & $\begin{array}{l}\text { Multiple fractures of } \\
\text { ribs. Pneumothorax }\end{array}$ & None & None & No & Nil & 1 & Survived \\
\hline 18 & 31 & Yes & None & None & $\begin{array}{l}\text { Multiple fractures of } \\
\text { ribs }\end{array}$ & $\begin{array}{l}\text { Fractures of lumbar } \\
\text { transverse process, } \\
\text { sacrum, pelvis, and } \\
\text { bones of } R \text {. foot }\end{array}$ & $\begin{array}{l}\text { Fall in urinary urea } \\
\text { concentration }\end{array}$ & No & Nil & 1 & Survived \\
\hline 19 & 83 & None & Yes & None & $\begin{array}{l}\text { Multiple fractures of } \\
\text { ribs }\end{array}$ & None & None & Yes & 3 days & 3 & Died \\
\hline 20 & 31 & Yes & None & None & $\begin{array}{l}\text { Multiple fractures of } \\
\text { ribs }\end{array}$ & $\begin{array}{l}\text { Fractures of pelvis } \\
\text { and lower leg. Facio- } \\
\text { maxillary injuries }\end{array}$ & None & Yes & 1 day & 3 & Died \\
\hline 21 & 52 & Yes & None & $\begin{array}{l}\text { Facio-maxil- } \\
\text { lasy fractures }\end{array}$ & $\begin{array}{l}\text { Multiple fractures of } \\
\text { ribs }\end{array}$ & None & None & No & Nil & 1 & Survived \\
\hline 22 & 34 & Yes & None & None & $\begin{array}{l}\text { Multiple fractures of } \\
\text { ribs. Fracture of } \\
\text { scapula. Laceration } \\
\text { of R. main bronchus. } \\
\text { Pneumonectomy. }\end{array}$ & None & None & Yes & 11 days & 3 & Survived \\
\hline 23 & 40 & Yes & None & None & $\begin{array}{l}\text { Multiple fractures of } \\
\text { ribs }\end{array}$ & None & None & No & Nil & 1 & Survived \\
\hline 24 & 74 & Yes & Yes & Lacerations & $\begin{array}{l}\text { Multiple fractures of } \\
\text { ribs }\end{array}$ & $\begin{array}{c}\text { Fractures of pelvis } \\
\text { and legs }\end{array}$ & None & Yes & Nil & 2 & Died \\
\hline 25 & 35 & None & None & None & $\begin{array}{l}\text { Multiple fractures of } \\
\text { ribs }\end{array}$ & None & None & Yes & 1 day & 3 & Died \\
\hline 26 & 59 & Yes & Yes & None & $\begin{array}{l}\text { Multiple fractures of } \\
\text { ribs }\end{array}$ & $\begin{array}{l}\text { Limb fractures. } \\
\text { Brachial artery } \\
\text { thrombosis. } \\
\text { Infarction of arm }\end{array}$ & None & No & Nil & 1 & Survived \\
\hline 27 & $5 \frac{1}{2}$ & Yes & None & None & $\begin{array}{l}\text { None, but } R \text {. pleural } \\
\text { effusion and pul- } \\
\text { monary contusion }\end{array}$ & $\begin{array}{l}\text { Intarction of arm } \\
\text { Laceration of liver }\end{array}$ & None & No & Nil & 1 & Survived \\
\hline 28 & 47 & Yes & Yes & None & $\begin{array}{l}\text { Multiple fractures of } \\
\text { ribs. Haemo- } \\
\text { pneumothorax }\end{array}$ & None & None & No & Nil & 1 & Survived \\
\hline 29 & 32 & Yes & Yes & None & $\begin{array}{l}\text { Multiple fractures of } \\
\text { ribs. Haemo- } \\
\text { pneumothorax }\end{array}$ & $\begin{array}{l}\text { Ruptured spleen. } \\
\text { Later required divi- } \\
\text { sion of abdomen } \\
\text { adhesions }\end{array}$ & None & Yes & 14 days & 3 & Survived \\
\hline 30 & 18 & None & None & $\begin{array}{l}\text { Severe facio- } \\
\text { maxillary }\end{array}$ & None & Fractured left femur & None & Yes & & 2 & Survived \\
\hline 31 & 35 & Yes & None & None & $\begin{array}{cc}\begin{array}{c}\text { Fractured } \\
\text { scapula. }\end{array} & \text { and } \\
\text { atelectasis } & \text { Patchy }\end{array}$ & None & None & No & Nil & 1 & Survived \\
\hline 32 & 70 & Yes & None & None & $\begin{array}{l}\text { Multiple fractures of } \\
\text { ribs }\end{array}$ & None & None & Yes & $\mathrm{Nil}$ & 2 & Survived \\
\hline 33 & 70 & Yes & Yes & None & $\begin{array}{l}\text { Multiple fractures of } \\
\text { ribs }\end{array}$ & None & None & Yes & Nil & 2 & Survived \\
\hline
\end{tabular}


suggested based principally on the degree of abnormality of blood-gas levels, and not on the extent of thoracic bony injuries. A series of 33 cases treated in the Respiratory Emergency Unit of Glasgow Royal Infirmary is presented and briefly discussed. A plea is made for frequent blood-gas analysis in the assessment of treatment of these cases.

We are grateful to Dr. A. C. Forrester and Dr. D. Campbell for their encouragement and criticism during the preparation of this paper. We acknowledge our debt to all members of the hospital staff who have contributed to the care of these patients in the Respiratory Emergency Unit, Glasgow Royal Infirmary.
REFERENCES

Andersen, O. S., Engel, K., Jørgensen, K., and Astrup, P. (1960). Scand. 7. clin. Lab. Invest., 12, 172.

Astrup, P. (1959). In Symposium on $\mathrm{pH}$ and Blood Gas Measuremont, edited by R. F. Woolmer. Churchill, London.

Bull, J. P. (1963). Ann. roy. Coll. Surg. Engl., 33, 175.

Comroe, J. H., Forster, R. E., Dubois, A. B., Briscoe, W. A., and Carlsen, E. (1962). The Lung: Clinical Physiology and Pulmonary Function Tests, 2nd ed., chap. 4. Year Book Medical Publishers, Chicago.

Freeman, J. (1963). Ann. roy. Coll. Surg. Engl., 33, 138.

Griffiths, H, W. C. (1960). F. roy. Coll. Surg. Edinb., 6, 13.

Griffiths, H. W. C. (1960). F. roy. Coll. Surg. Edinb. 6,

Kennedy, A. C., Luke, R. G., Campbell, D., and Cannon, R. N. (1963). Lancet, 2, 1304 .

Maloney, J. V., Schmutzer, K. J., and Raschke, E. (1961). f. thorac. cardiovasc., Surg., 41, 291.

Nahas, G. G. (1963)., Clin. Pharmacol. Ther., 4, 784.

Telford, J., and Keats, A. S. (1961). Anesthesiology, 22, 465

Whitwam, J. G., and Norman, J. (1964). Brit. med. J., 1, 349.

\title{
Diagnosis and Treatment of Erythema Induratum (Bazin)
}

\author{
MICHAEL FEIWEL,* M.B., M.R.C.P. ; DOWLING D. MUNRO, † M.B., M.R.C.P.
}

Brit. med. F., 1965, 1, 1109-1111

Bazin (1861) gave the name of erythema induratum to a nodular eruption which occurred on the lower legs of young women who had tuberculosis. He commented that the condition was not rare. In the next 30 years the disease attracted little notice until, with the discovery of the tubercle bacillus, interest revived and attempts were made, with varying success, to isolate the bacillus from the lesions.

Later, other clinical conditions were described resembling erythema induratum but which were not tuberculous. This, and the declining incidence of tuberculosis generally, may be the reasons why erythema induratum does not now receive sufficient consideration. We wish to draw attention to erythema induratum particularly because of the influx of tuberculosis-prone individuals from overseas. We believe that Bazin's disease is not uncommon in Britain to-day and that it is often misdiagnosed. Even when the diagnosis has been made patients may not receive adequate antituberculous therapy because the physician may not be convinced that he is dealing with a manifestation of active tuberculosis.

Cases.-Table I is a summary of the case histories and investigations in 12 patients with erythema induratum (Bazin). Table II gives their treatment and the clinical response.

\section{Differential Diagnosis}

Disorders of the lower legs characterized by indurated plaques or nodules with or without ulceration present a somewhat complex diagnostic problem. The concept that all were not of the Bazin type was first discussed by Audry (1898), and later by Galloway (1899). However, Whitfield's (1901) name is particularly associated with a form of erythema induratum that is not tuberculous. Montgomery et al. (1944) stated that the following nodular vascular disorders of the legs have many features in common: nodular vasculitis, erythema induratum, erythrocyanosis and pernio, erythema nodosum, panniculitis, recurrent idiopathic thrombophlebitis, and indurated cellulitis secondary to chronic venous stasis. Nodular vasculitis was the term they proposed for the type of case described by Whitfield.

Willkinson (1954) expanded the concept of nodular vasculitis to include a group of disorders with a common vascular basis. In most of these he stressed the aetiological importance of cold

\footnotetext{
- Consultant Dermatologist, St. Mary's Hospital, Paddington General Hospital, North Middlesex Hospital, and 'St. Charles' Hospital, London. † Senior Registrar, Dermatology Department, St. Mary's Hospital,
}

and peripheral venous stasis. He remarked on the additional effect of tuberculosis in some cases, and stated that "The question resolves itself into what part, if any, the tuberculous process plays in a given lesion, even if the disease is active in the patient. One cannot afford to be too sceptical."

As a result of the present study we believe that the role of tuberculosis should be emphasized, and that a case of erythema induratum should be considered to be of tuberculous origin unless reasons for excluding this are particularly strong. Telford's (1937) view that erythema induratum is the same condition as erythrocyanosis and is never tuberculous cannot be accepted. Nor do we agree with Sandberg and Adams (1962), who regard erythema induratum merely as a descriptive term that does not denote a specific tuberculous aetiology.

In our cases wrong diagnoses were prominent and as a result several patients had prolonged disability. Emphasis that Bazin's disease occurs in young women whereas nodular vasculitis is seen in the middle-aged may account for the diagnosis of nodular vasculitis made in some of our patients without sufficient investigation. Two-thirds of our patients were over the age of 35 , and it is important to realize that erythema induratum is not confined to younger age groups but may occur later, even in the sixties. One patient of Montgomery et al. (1944), a woman aged 54-diagnosed as having nodular vasculitis because clinical, pathological, and bacteriological investigation had failed to disclose any evidence of tuberculosis-developed a tuberculous cervical adenitis within six months, and then showed a strongly positive tuberculin reaction. In addition to nodular vasculitis other diagnoses had included thrombophlebitis migrans, perniosis, erythema nodosum, and collagen disease, and the patients had failed to respond to treatment. Those previously recognized as having Bazin's disease had received insufficient or inadequate antituberculous therapy and had relapsed.

\section{Clinical Features}

Most patients showed typical clinical features of erythema induratum. Frequently they presented with crops of small, tender, and painful erythematous or dusky nodules of $1 \mathrm{~cm}$. diameter or less occurring on the lower legs. Some of these nodules ulcerated, often with aggravation of pain. The influence of cold and peripheral vascular stasis could be observed in half of those patients who were worse in winter and in whom nodules tended to occur particularly in the calves and back of the ankles. Females outnumbered men by 11 to 1 . 